\title{
MYCOBACTERIUM TUBERCULOSIS: DRUG RESISTANCE, VIRULENCE AND POSSIBLE SOLUTIONS
}

\author{
Danilenko VN ${ }^{1,2}$, Zaychikova $\mathrm{MV}^{1}$, Dyakov $\mathrm{IN}^{3}$, Shur KV${ }^{1}$, Maslov DA ${ }^{1}$ \\ ${ }^{1}$ Laboratory of Bacterial Genetics, Department Genetics and Biotechnology, Vavilov Institute of General Genetics, Moscow \\ 2 BIOAN Research Center for Biotechnology of Antibiotics, Moscow \\ ${ }^{3}$ Laboratory of Immunoglobulin Biosynthesis, Mechnikov Research Institute of Vaccine and Sera, Moscow
}

In spite of successful measures taken to reduce mortality associated with tuberculosis, this disease is still widely spread. In some Russian regions the number of patients with tuberculosis is no short of the epidemic level. The long-term use of antibiotics, changes in the composition of the human microbiota and a few other factors have contributed to the emergence of drug-resistant and hypervirulent sublineages of Mycobacterium tuberculosis. Insufficient fundamental knowledge of mechanisms underlying the emergence and evolution of $M$. tuberculosis clones simultaneously resistant to a wide spectrum of antibiotics and exhibiting increased virulence complicates the situation and necessitates a new strategy to combat the disease. The key concepts of this strategy are «superorganism», «microbiota» and «resistome». The emergence of multidrugresistant (MDR) and extensively drug-resistant (XDR) strains should be addressed in the context of the "Superorganism"; among its components are the human body, its microbiota (specifically, the bacteria that affect the immune status), and M. tuberculosis itself. Clinically studied phenotypes and genotypes of MDR/XDR strains are a result of clonal variability that M. tuberculosis develops as part of this «superorganism». Therefore, it is important to focus on the development of vaccines, adjuvants and probiotics with selective immunomodulating and antioxidant properties.

Keywords: tuberculosis, Mycobacterium tuberculosis, drug resistance, adjuvants, vaccines, cross-drug resistance

Funding: this work was supported by the Project of the Ministry of Education and Science of the Russian Federation «The role of region-specific polymorphisms of virulence genes in the formation of drug resistance of Mycobacterium tuberculosis» (Project ID RFMEFI61317X0068).

$\triangle$ Correspondence should be addressed: Valery N. Danilenko

Gubkina 3, Moscow, 119991; valerid@vigg.ru

Received: 05.06.2018 Accepted: 10.07.2018

DOI: $10.24075 /$ brsmu.2018.038

\section{MYCOBACTERIUM TUBERCULOSIS: ПРОБЛЕМЫ ЛЕКАРСТВЕННОЙ УСТОЙЧИВОСТИ, ВИРУЛЕНТНОСТИ И ПОДХОДЫ К ИХ РЕШЕНИЮ}

\author{
В. Н. Даниленко ${ }^{1,2}$, М. В. Зайчикова', И. Н. Дьяков ${ }^{3}$, К. В. Шур¹, Д. А. Маслов ${ }^{1}$ \\ 1 Лаборатория генетики микроорганизмов, отдел генетических основ биотехнологии, Институт общей генетики имени Н. И. Вавилова, Москва \\ 2 Научно-исследовательский центр биотехнологии антибиотиков «БИОАН», Москва \\ з Лаборатория биосинтеза иммуноглобулинов, Научно-исследовательский институт вакцин и сывороток имени И. И. Мечникова, Москва
}

\begin{abstract}
Несмотря на достигнутые успехи мероприятий, направленных на снижение смертности от туберкулеза, данное заболевание по прежнему крайне распространено, а в некоторых регионах России численность больных достигает показателей, характерных для уровня эпидемии. Многолетнее широкое применение антибиотиков, изменение состава микробиоты человека и ряд других факторов привели к появлению лекарственноустойчивых и высоковирулентных сублиний Mycobacterium tuberculosis. Недостаточность уровня и объема фундаментальных знаний о механизмах возникновения и формирования клонов M. tuberculosis, одновременно устойчивых ко многим антибиотикам и обладающих повышенной патогенностью, усложняет проблему и требует разработки новой концепции борьбы с туберкулезом. Ключевые понятия этой концепции - «суперорганизм», «микробиота» и «резистом». Возникновение форм с множественной (МЛУ) и широкой (ШЛУ) лекарственной устойчивостью следует рассматривать в контексте их формирования в составе некоторого суперорганизма, элементами которого являются собственно организм человека, его микробиота (в том числе влияющая на иммунный статус) и M. tuberculosis. Клинически тестируемые фенотипы и генотипы штаммов МЛУ/ШЛУ формируются на основе клональной изменчивости M. tuberculosis в «суперорганизме». Поэтому при разработке противотуберкулезных препаратов следует обращать особое внимание на создание вакцин, адъювантов и пробиотиков с селективными иммуномодулирующими и антиоксидантными свойствами.
\end{abstract}

Ключевые слова: туберкулез, Mусоbacterium tuberculosis, лекарственная устойчивость, адъюванты, вакцины, перекрестная лекарственная устойчивость

Финансирование: работа была выполнена в рамках проекта Министерства образования и науки Российской Федерации №RFMEFI61317X0068 «Роль регион-специфичных полиморфизмов генов вирулентности в формировании лекарственной устойчивости Mycobacterium tuberculosis».

$\bowtie$ Для корреспонденции: Валерий Николаевич Даниленко ул. Губкина, д. 3, г. Москва, 119991; valerid@vigg.ru

Статья получена: 05.06.2018 Статья принята к печати: 10.07.2018

DOI: $10.24075 /$ vrgmu.2018.038 
In 2017 the Russian government adopted a strategy to prevent the spread of antimicrobial resistance in the Russian Federation by 2030. One of the goals set by the strategy is to study the mechanisms underlying the emergence of antimicrobial resistance and to develop novel antimicrobial medications, alternative methods, technologies and means of prevention, diagnosis and treatment of infectious diseases in humans, animals and plants.

According to the 2016 report by the World Health Organization, that year tuberculosis reached the incidence of 10.4 million new cases and killed 1.8 million people becoming the leading cause of death associated with infection [1]. Mycobacterium tuberculosis is the causative agent of tuberculosis. The emergence and spread of its multidrugresistant (MDR) and extensively drug-resistant (XDR) strains are the central challenges in the battle against this disease [2-4]. Statistically, $4 \%$ of new and $21 \%$ of previously treated cases are multidrug-resistant. In Russia these numbers are 22\% and $53 \%$, respectively. To survive, mycobacteria can evolve new mechanisms of resistance in response to any currently known drug. They are also naturally resistant to antibiotics, being equipped with a large arsenal of genes and genetic systems that make up the resistome. Proposed in 2006, the resistome concept refers to the set of antibiotic resistance determinants, including resistance genes that are intrinsic to a certain bacterial strain, organism or ecosystem $[5,6]$. The resistome of M. tuberculosis comprises genes coding for different protein classes, such as transporters, proteins that modify the targets or chemical structure of pharmaceutical drugs, transcription factors involved in stress response, and some others.

Another alarming trend is the emergence of previously unknown hypervirulent $M$. tuberculosis sublineages [7-9]. In vitro and in vivo studies carried out in macrophage and mouse models, respectively, have established an association between virulence and a genotype the pathogen belongs to [10]. Increased virulence is mostly observed in the Beijing genotype (lineage). Its epidemiological significance cannot be overestimated as it continues to spread globally and tends to frequently evolve into MDR forms [11, 12]. The Beijing strains are genetically heterogenous branching off into a few sublineages. Although the high frequency of increasingly virulent and drugresistant forms is generally typical for the entire Beijing family, it still varies among its sublineages [13, 14]. Moreover, the clinically significant characteristics of these bacteria can vary among the strains representing the same sublineage.

Over the past decades, the study of mechanisms underlying the emergence of MDR/XDR strains of $M$. tuberculosis, the discovery of antibiotics capable of killing these strains and the development of genetically engineered vaccines and adjuvants to prevent and treat the disease have helped the researchers to identify a few important problems [15]. We cannot develop a novel effective drug unless we understand molecular and genetic mechanisms underlying the emergence and evolution of multiple drug resistance and virulence.

\section{Drug resistance and development of novel antituberculosis antibiotics}

Bacteria are not limited to acquired drug resistance. They are also naturally, though not so strongly, resistant to antibiotics. When M. tuberculosis cells are exposed to an antibacterial agent, the pathogen activates its transcription factors that regulate the expression of genes responsible for the modification of the drug or its target and activation of reverse transport systems that pump the drug or its derivatives out of the bacterial cell. Genes underpinning the mechanisms that ensure natural resistance to antibiotics are targeted by a variety of biological factors including antibiotics, which affects their expression and therefore reduces susceptibility to drugs.

The use of antibiotics for treating co-infections in patients with tuberculosis or their absorption with food can contribute to increasing drug resistance of $M$. tuberculosis.

In 2015 there were over 580,000 patients infected with MDR and XDR tuberculosis strains worldwide. Their dramatic spread was driven by the long-term use of the same old medications. It was not until recently that bedaquiline, the first new antituberculosis drug in 40 years, was introduced into clinical practice [16].

In this light, development of novel antituberculous drugs is becoming a task of paramount importance. These pharmaceutical agents are expected to satisfy a number of requirements, such as high antimicrobial activity against both drug-sensitive and MDR strains of M. tuberculosis and excellent specificity to a new biological target. At present, development of novel antituberculosis drugs that have a potential to overcome the phenomenon of drug resistance and/ or to reduce the length of treatment is carried out by the leading pharmaceutical companies and research groups all over the world, including Lilly TB Drug Discovery Initiative, GSK, Roche, Sanofi, TB Alliance, Colorado State University, and some others (http://www.newtbdrugs.org).

In Russia, research in this field was stimulated by the Pharma-2020 federal program. For example, Vavilov Institute of General Genetics, Moscow, has been conducting a series of preclinical trials in collaboration with medicinal chemists from state-funded and commercial research institutions, such as Postovsky Institute of Organic Synthesis, the Ural Branch of RAS; Gause Institute of New Antibiotics; Novosibirsk Institute of Organic Chemistry, the Siberian Branch of RAS; Zelinsky Institute of Organic Chemistry; BIOAN Research Center, and New Science Technologies Ltd. The tested drugs belong to new classes of medical compounds, such as derivatives of usnic acid [17], substituted azolo(1,2,4,5)tetrazines [18], aminopyridines and aminopyrimidines[19], and aminopurine derivatives [20].

The advent of the postgenomic era witnessed two approaches to the discovery of novel antituberculosis drugs: target-to-drug and drug-to-target [21-23].

Unfortunately, the first approach did not fully live up to the expectations. Many drug candidates with good inhibiting properties exhibited against the target enzyme in vitro either were not active against $M$. tuberculosis in vitro due to the low permeability of the bacterial cell wall or were ineffective in in vivo models because the target was no longer vitally important for the bacteria under those conditions [22, 24].

Yet there are a few successful experiments worth mentioning. In one of them, a compound termed BDM31343 was identified capable of inhibiting EtHR, the EthA repressor which, in turn, activated ethionamide [25]. This compound was shown to increase susceptibility of mycobacteria to ethionamide enhancing its effect threefold in mouse models [26].

Because the target-to-drug approach proved to be less than effective, researchers turned to a more traditional drug-totarget search strategy based on whole-cell screening [24]. All drugs currently used to treat tuberculosis, including bedaquiline, pretomanid, delamanid, Q203, SQ-109, and BTZ043, were discovered using this approach [27].

The drug-to-target search strategy often involves highthroughput screening against $M$. tuberculosis H37Rv cultures and related $M$. bovis BCG and $M$. smegmatis model strains 
$[24,28]$. The libraries of chemical compounds used in such experiments are enormously huge. For example, GSK researchers consecutively screened a total of 2 million compounds against $M$. bovis BCG and $M$. tuberculosis H37Rv to select 7 low-toxic drug candidates exhibiting high activity and capable of diffusing through the cell membrane [29].

The drug-to-target approach entails the need for wholegenome sequencing of antibiotic-resistant mutants in order to identify potential biotargets and for further research aimed at confirming the activity of selected drug candidates against those targets [24].

The discovery of drugs capable of killing persistent forms of $M$. tuberculosis remains a global challenge. So far, pyrazinamide appears to be the most effective antibiotic against persistent $M$. tuberculosis [30]. Resistance to pyrazinamide can significantly worsen clinical prognosis, especially in patients with MDR tuberculosis [31, 32].

\section{Development of antituberculosis vaccines}

Although vaccination against tuberculosis is advocated everywhere, the incidence of the disease remains abnormally high. This can be explained by the low efficacy of the BCG vaccine used for global immunization, which varies between $0 \%$ and $80 \%$ depending on the individual's age, immune status, area of residence, etc. [33]. Among other reasons reducing the efficacy of the vaccine is the genetic diversity of the pathogen. It is hypothesized that resistance to vaccination demonstrated by the ubiquitous Beijing strains may explain their evolutional success [11]. Considering that, creation of novel vaccines against tuberculosis should be a top-priority task.

Development of such vaccines has taken two paths. The first is to use the attenuated pathogen itself. For this purpose, deletion mutants of $M$. tuberculosis are being engineered. Among the knocked-out genes are those coding for virulence factors, such as Mce (mammalian cell entry) proteins facilitating pathogen invasion; PPE proteins; proteins participating in lipid synthesis; sigma factors; two-component systems, and some others.

The second approach is to compose a subunit vaccine containing genetically engineered pathogen antigens [34, 35]. Advantageously, such vaccines are highly specific, have a low allergenic potential, are easy to fabricate, cost-effective, and convenient to store and transport [36].

Candidate proteins for next-generation vaccines include secretory proteins of the Ag85 complex that interact with T cells; TB10.4 (rv0288); Hsp65; PE and PPE proteins. The greatest promise is held by the protein components of the ESAT6 and CFP secretion systems [36].

However, in spite of the considerable interest in this field, genetically engineered vaccines did not live up to the expectations. The main drawback of such vaccines is their low immunogenicity.

The key challenge in the development of genetically engineered vaccines is the selection of optimal antigens [36]. Here, strong antigenic potential is exhibited by the structural elements conferring pathogenicity, of which $M$. tuberculosis has over 300; some of them have already been segregated to design a subunit vaccine [37]. Many of these genes typically have a single nucleotide polymorphism resulting in an amino acid substitution, which affects the structure of the protein modulating its antigenic activity. At present, the intraspecies diversity of $M$. tuberculosis is unfairly overlooked in the production of genetically engineered vaccines, which are usually based on a sequence of the standard laboratory strain H37Rv. If cultured for too long, the M. bovis strain used for BCG production can develop mutations (a natural consequence of its microevolution) reducing the efficacy of the vaccine [38]. It is possible that the antigenic activity of proteins is not identical in different $M$. tuberculosis strains.

Another promising area of research is related to the development of a candidate mucosal vaccine against tuberculosis that induces the sustained local mucosal immune response. The importance of the local immunity against tuberculosis has been demonstrated in a number of works. It has been shown that intranasal administration of protective IgA, pretreatment of virulent $M$. tuberculosis with protective IgA and intranasal administration of $M$. bovis BCG trigger a sustained immune response to $M$. tuberculosis infection. [39-42]. The mucosal vaccine administered alone or in combination with its subcutaneous form could offer a solution to the problems accompanying BCG vaccination.

It should be noted, though, that so far none of the mentioned vaccines have been introduced into clinical practice. Again, the drawback of such vaccines is their low immunogenicity necessitating the use of adjuvants.

\section{Prospects for the development of antituberculosis vaccine adjuvants based on probiotic strains}

An adjuvant is a compound with non-specific activity that enhances the immune response to antigens administered in combination with adjuvants [43]. Of all commonly used adjuvants, aluminum hydroxide and aluminum phosphate are the most remarkable [44]. However, the boosting effect of these compounds is not always sufficient. Other substances that can serve as adjuvants include synthetic polyoxidonium and chitosan, a naturally obtained polysaccharide. Bacterial cell components are also tested for their adjuvant properties, specifically those that contain pathogen-associated molecular patterns (PAMP) triggering the immune response. A few works have already described the adjuvant effects of lactic acid bacteria [45], bacterial cell wall components [46, 47], the fibronectin-binding protein 1 of Streptococcus pyogenes [48], surface flagellins [49], etc.

Some strains of probiotic bacteria, bifidobacteria in particular, can trigger production of Th17 and Th1 cytokines [50] that play an important role in the induction of the mucosal immune response against tuberculosis [39]. Administered intranasally, probiotics can exert their vaccine-boosting effect, inducing protective immunity against virulent strains of $M$. tuberculosis. Commensal bifidobacteria and lactobacilli are capable of stimulating the mechanisms of protective immunity, regulating the secretion of both pro- and anti-inflammatory cytokines. As a rule, in vitro studies of the immunomodulating activity of bacterial strains employ intestinal cell lines (Caco-2, HT-29) or immunocytes (EC-6, THP-1). Similar in vivo experiments are carried out in lab animals (healthy or with compromised immunity, gnotobiotic or those with experimentally induced infections or non-infectious pathologies) [51, 52].

It should be noted that different strains of bifidobacteria and lactobacilli, as well as their components, have different immunomodulating effects in terms of intensity [53-55]. Lactobacilli and bifidobacteria have already demonstrated their adjuvant effects in the vaccines against viruses [56, 57], streptococci [58], and allergies [48, 59]. Intranasal lactobacilli boost local mucosal immunity and modulate systemic mechanisms of the immune defense, increasing resistance to the respiratory syncytial $[56,57,60]$ and influenza viruses. These findings allow us to conclude that intranasally administered probiotics can act as adjuvants to a vaccine, 


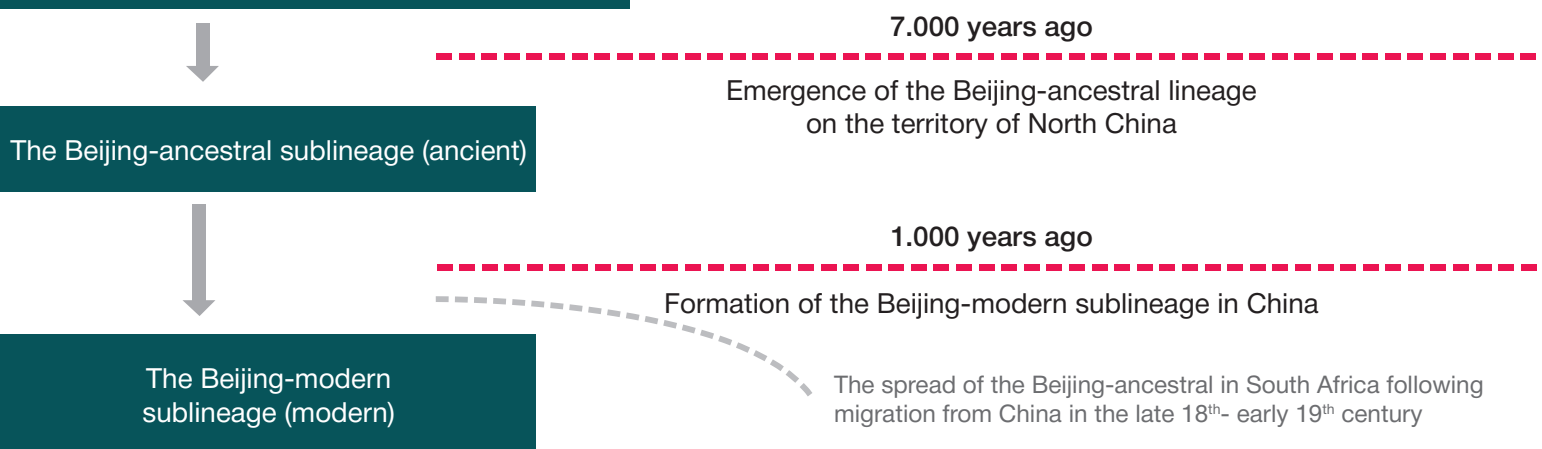

\section{0 years ago}
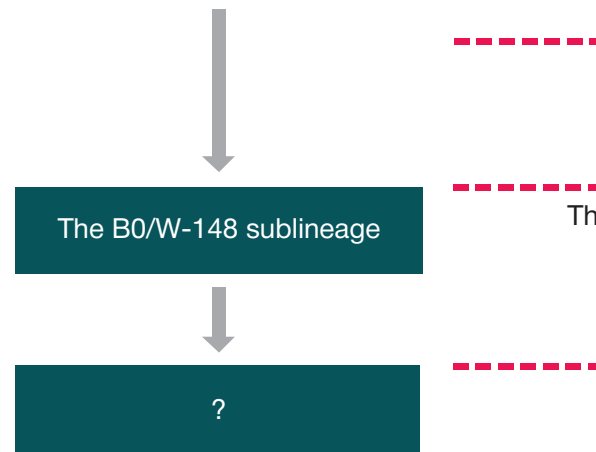

The Beijing-modern sublineage appears on the territory of Russia,

brought there by the migrants

50 years ago (the era of antibiotics)

The B0/W sublineage branches off from the Beijing-modern sublineage in the Russian Federation

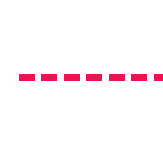

\section{Present day}

Globally observed changes in the immune status of the world population resulting from HIV, chronic conditions and stress

Fig. 1. Evolution of the Beijing lineages. Wide use of antibiotics in the recent decades has provided selective advantage to the B0/W-14 strain characterized by a high level of drug resistance

effectively inducing the protective immune response against M. tuberculosis in the mucosa.

\section{CONCLUSION}

Throughout their history, humans have been colonized by latent and active M. tuberculosis [61]. The Beijing strains that emerged on the territory of modern China about 7, 000 years ago and have widely spread across the world since then are a live example of the ongoing evolution of the pathogen that still forms new sublineages, such as B0/W-148 (Fig. 1) [62, 63].

It is known that susceptibility to tuberculosis is affected by the level of gene expression in T cells [64]. In this light, the problem of drug resistance and increased virulence and the discovery of a new generation of antituberculosis drugs should be addressed in the context of the "superorganism" concept. The antibiotic-based treatment of tuberculosis affects not only the pathogen, but the host as well, altering the microbiota composition and, therefore, compromising the immunity, which is known to be directly affected by the gut microbiota. Antibiotics interfere with the functions of the central and peripheral nervous systems of the host; other systems and organs may also be affected. The unregulated use of antibiotics in agriculture leads to the formation of cross-resistance to drugs in bacteria. Besides, antibiotic-based therapies can "wake" the latent tuberculosis infection.

To sum up, the major factor that has been stimulating the positive selection of drug-resistant virulent forms of $M$. tuberculosis over the past 60 years is the uncontrolled use of antibiotics. Other factors include the wide spread of immunitycompromising diseases, such as HIV, type 2 diabetes mellitus, hepatitis B, etc. Diet and migration stimulated by globalization lead to the shifts in the gut microbiota composition, which in turn make their contribution to the problem. The genetic diversity of $M$. tuberculosis shaped by single nucleotide polymorphisms in the genes responsible for virulence, natural resistance to drugs and persistence, IS elements and possibly CRISPR-cas systems also affect the adaptation of the pathogen to the host $[65,66]$.

Advances in epidemiology, molecular genetics, comparative genomics, proteomics and systemic biology have improved our understanding of the multifactorial nature of tuberculosis revealing the need for a tailored approach to the treatment of this disease.

\section{References}

1. World Health Organization. Global tuberculosis report 2016. Available from: http://www.searo.who.int/tb/documents/globaltuberculosis-report-2016/en/

2. Prozorov AA, Zaichikova MV, Danilenko VN. Mycobacterium tuberculosis mutants with multidrug resistance: History of origin, genetic and molecular mechanisms of resistance, and emerging challenges. Russian Journal of Genetics. 2012; 48 (1): 1-14.

3. Dean AS, Cox H, Zignol M. Epidemiology of Drug-Resistant
Tuberculosis. Adv Exp Med Biol. 2017: 1019: 209-20.

4. Lange C, Chesov D, Heyckendorf J, Leung CC, Udwadia Z, Dheda K. Drug-resistant tuberculosis: An update on disease burden, diagnosis and treatment. Respirology. 2018. DOI: 10.1111/resp.13304. [Epub ahead of print].

5. D'Costa VM, McGrann KM, Hughes DW, Wright GD. Sampling the antibiotic resistome. Science. 2006; 311 (5759): 374-7.

6. Wright GD. The antibiotic resistome: the nexus of chemical and 
genetic diversity. Nat Rev Microbiol. 2007; 5 (3): 175-86.

7. Mikheecheva NE, Zaychikova MV, Melerzanov AV, Danilenko VN. A nonsynonymous SNP catalog of Mycobacterium tuberculosis virulence genes and its use for detecting new potentially virulent sublineages. Genome Biol Evol. 2017; 9 (4): 887-99.

8. Zaychikova MV, Zakharevich NV, Sagaidak MO, Bogolubova NA Smirnova TG, Andreevskaya SN, et al. Mycobacterium tuberculosis Type II Toxin-Antitoxin Systems: Genetic Polymorphisms and Functional Properties and the Possibility of Their Use for Genotyping. PLoS One. 2015; 10: e0143682.

9. Reiling N, Homolka S, Kohl TA, Steinhäuser C, Kolbe K, Schütze S, et al. Shaping the niche in macrophages: Genetic diversity of the M. tuberculosis complex and its consequences for the infected host. Int J Med Microbiol. 2017; pii: S1438-4221 (17) 30294-1.

10. Reiling N, Homolka S, Walter K, Brandenburg J, Niwinski L, Ernst M, et al. Clade specific virulence patterns of Mycobacterium tuberculosis complex strains in human primarymacrophages and aerogenically infected mice. MBio. 2013; e00250-13.

11. Hanekom M, Gey van Pittius NC, McEvoy C, Victor TC, Van Helden PD, Warren RM. Mycobacterium tuberculosis Beijing genotype: a template for success. Tuberculosis (Edinb). 2011; 91 (6): 510-23.

12. Zaychikova MV, Mikheecheva NE, Belay YO, Alekseeva MG, Melerzanov AV, Danilenko VN. Single nucleotide polymorphisms of Beijing lineage Mycobacterium tuberculosis toxin-antitoxin system genes: their role in the changes of protein activity and evolution. Tuberculosis (Edinb). 2018; 112: 11-19.

13. Ebrahimi-Rad M, Bifani P, Martin C, Kremer K, Samper S, Rauzier $\mathrm{J}$, et al. Mutations in putative mutator genes of Mycobacterium tuberculosis strains of the W-Beijing family. Emerg Infect Dis. 2003; 9 (7): 838-45.

14. Ribeiro SC, Gomes LL, Amaral EP, Andrade MR, Almeida FM, Rezende AL, et al. Mycobacterium tuberculosis strains of the modern sublineage of the Beijing family are more likely to display increased virulence than strains of the ancient sublineage. J Clin Microbiol. 2014; 52 (7): 2615-24.

15. Kaufmann SH, Evans TG, Hanekom WA. Tuberculosis vaccines: time for a global strategy. Sci Transl Med. 2015; 7 (276): 276fs8.

16. Chahine EB, Karaoui LR, Mansour H. Bedaquiline: a novel diarylquinoline for multidrug-resistant tuberculosis. Ann Pharmacother. 2014; 48 (1): 107-15.

17. Bekker OB, Sokolov DN, Luzina OA, Komarova NI, Gatilov YV, Andreevskaya SN, et al. Synthesis and activity of (+)-usnic acid and (-)-usnic acid derivatives containing 1,3-thiazole cycle against Mycobacterium tuberculosis. Med Chem Res. 2015; 24 (7): 2926-38

18. Maslov DA, Bekker OB, Danilenko VN. New Test System for Serine/Threonine Protein Kinase Inhibitors Screening. Patent RF № 2566998, 27.10.2015.

19. Maslov DA, Bekker OB, Alekseeva MG, Kniazeva LM, Mavletova DA Afanasyev II, et al. Aminopyridine- and aminopyrimidine-based serine/threonine protein kinase inhibitors are drug candidates for treating drug-resistant tuberculosis. Bulletin of Russian State Medical University. 2017; 1: 38-43.

20. Krasnov VP, Vigorov AY, Musiyak W, Nizova IA, Gruzdev DA, Matveeva TV, et al. Synthesis and antimycobacterial activity of $\mathrm{N}$-(2-aminopurin-6-yl) and $\mathrm{N}$-(purin-6-yl) amino acids and dipeptides Bioorg Med Chem Lett. 2016; 26 (11): 2645-8.

21. Sala C, Hartkoorn RC. Tuberculosis drugs: new candidates and how to find more. Future Microbiol. 2011; 6 (6): 617-33.

22. Lechartier B, Rybniker J, Zumla A, Cole ST. Tuberculosis drug discovery in the post-post-genomic era. EMBO Mol Med. 2014; 6 (2): 158-68.

23. Danilenko VN, Osolodkin DI, Lakatosh SA, Preobrazhenskaya MN, Shtil AA. Bacterial eukaryotic type serine-threonine protein kinases: from structural biology to targeted anti-infective drug design. Curr Top Med Chem. 2011; 11 (11): 1352-69.

24. Cooper CB. Development of Mycobacterium tuberculosis whole cell screening hits as potential antituberculosis agents. J Med Chem. 2013; 56 (20): 7755-60.

25. Baulard AR, Betts JC, Engohang-Ndong J, Quan S, McAdam RA, Brennan PJ, et al. Activation of the pro-drug ethionamide is regulated in mycobacteria. J Biol Chem. 2000; 275 (36): 28326-31.
26. Willand $\mathrm{N}$, Dirié $\mathrm{B}$, Carette $\mathrm{X}$, Bifani $\mathrm{P}$, Singhal $\mathrm{A}$, Desroses $\mathrm{M}$, et al. Synthetic EthR inhibitors boost antituberculous activity of ethionamide. Nat Med. 2009; 15 (5): 537-44.

27. Andries K, Verhasselt P, Guillemont J, Göhlmann HW, Neefs JM, Winkler $\mathrm{H}$, et al. A diarylquinoline drug active on the ATP synthase of Mycobacterium tuberculosis. Science. 2005; 307 (5707): 2237.

28. Ananthan S, Faaleolea ER, Goldman RC, Hobrath JV, Kwong CD, Laughon BE, et al. High-throughput screening for inhibitors of Mycobacterium tuberculosis H37Rv. Tuberculosis (Edinb). 2009; 89 (5): 334-53.

29. Ballell L, Bates RH, Young RJ, Alvarez-Gomez D, Alvarez-Ruiz E, Barroso V, et al. Fueling open-source drug discovery: 177 smallmolecule leads against tuberculosis. Chem Med Chem. 2013; 8 (2): 313-21.

30. Zhang $Y$, Mitchison D. The curious characteristics of pyrazinamide: a review. Int J Tuberc Lung Dis. 2003; 7 (1): 6-21.

31. Zhang $Y$, Chiu Chang K, Leung C-C, Wai Yew W, Gicquel B, Fallows D, et al. 'ZS-MDR-TB' versus 'ZR-MDR-TB': improving treatment of MDR-TB by identifying pyrazinamide susceptibility. Emerg Microbes Infect. 2012; 1 (7): e5.

32. Maslov DA, Zaŭchikova MV, Chernousova LN, Shur KV, Bekker OB, Smirnova TG, et al. Resistance to pyrazinamide in Russian Mycobacterium tuberculosis isolates: pncA sequencing versus Bactec MGIT 960. Tuberculosis (Edinb). 2015; 95 (5): $608-12$.

33. Mangtani P, Abubakar I, Ariti C, Beynon R, Pimpin L, Fine PE, et al. Protection by BCG vaccine against tuberculosis: a systematic review of randomized controlled trials. Clin Infect Dis. 2014; 58 (4): 470-80.

34. Kaufmann SH, Weiner J, von Reyn CF. Novel approaches to tuberculosis vaccine development. Int J Infect Dis. 2017; 56: 263-7.

35. Méndez-Samperio P. Global Efforts in the Development of Vaccines for Tuberculosis: Requirements for Improved Vaccines Against Mycobacterium tuberculosis. Scand J Immunol. 2016; 84 (4): 204-10

36. Andersen $\mathrm{P}$, Kaufmann $\mathrm{SH}$. Novel vaccination strategies against tuberculosis. Cold Spring Harb Perspect Med. 2014; 4 (6). pii: a018523.

37. Forrellad MA, Klepp L, Gioffré A, Sabioy García J, Morbidoni HR, de la Paz Santangelo $M$, et al. Virulence factors of the Mycobacterium tuberculosis complex. Virulence. 2013; 4 (1): 3-66.

38. Brosch R, Gordon SV, Garnier T, Eiglmeier K, Frigui W, Valenti P, et al. Genome plasticity of BCG and impact on vaccine efficacy. Proc Natl Acad Sci USA. 2007; 104 (13): 5596-601.

39. Uranga S, Marinova D, Martin C, Aguilo N. Protective Efficacy and Pulmonary Immune Response Following Subcutaneous and Intranasal BCG Administration in Mice. J Vis Exp. 2016; 115. DOl: $10.3791 / 54440$.

40. Zimmermann N, Thormann V, Hu B, Köhler AB, Imai-Matsushima A, Locht $C$, et al. Human isotype-dependent inhibitory antibody responses against Mycobacterium tuberculosis. EMBO Mol Med. 2016; 8 (11): 1325-39.

41. Alvarez N, Infante JF, Borrero R, Mata D, Payan JB, Hossain MM, et al. Histopathological Study of the Lungs of Mice Receiving Human Secretory IgA and Challenged with Mycobacterium tuberculosis. Malays J Med Sci. 2014; 21 (3): 31-7.

42. Alvarez N, Otero O, Camacho F, Borrero R, Tirado Y, Puig A, et al. Passive administration of purified secretory IgA from human colostrum induces protection against Mycobacterium tuberculosis in a murine model of progressive pulmonary infection. BMC Immunol. 2013; 14 (Suppl 1): S3.

43. Savelkoul HFJ, Ferro VA, Strioga MM, Schijns VEJ.C. Choice and Design of Adjuvants for Parenteral and Mucosal Vaccines. Vaccines (Basel). 2015; 3 (1): 148-71.

44. Edelman R. Vaccine adjuvants. Rev Infect Dis. 1980; 2 (3): 370-83.

45. Pouwels PH, Leer RJ, Shaw M, Heijne den Bak-Glashouwer MJ, Tielen FD, Smit E, et al. Lactic acid bacteria as antigen delivery vehicles for oral immunization purposes. Int $\mathrm{J}$ Food Microbiol. 1998; 41 (2): 155-67.

46. Bessler WG, Huber M, Baier W. Bacterial cell wall components 
as immunomodulators-II. The bacterial cell wall extract OM-85 BV as unspecific activator, immunogen and adjuvant in mice Int $J$ Immunopharmacol. 1997; 19 (9-10): 551-8.

47. López P, González-Rodríguez I, Sánchez B, Gueimonde M, Margolles A, Suárez A. Treg-inducing membrane vesicles from Bifidobacterium bifidum LMG13195 as potential adjuvants in immunotherapy. Vaccine. 2012; 30 (5): 825-9.

48. Medina E, Talay SR, Chhatwal GS, Guzmán CA. Fibronectinbinding protein I of Streptococcus pyogenes is a promising adjuvant for antigens delivered by mucosal route. Eur J Immunol. 1998; 28 (3): 1069-77.

49. Mizel SB, Bates JT. Flagellin as an adjuvant: cellular mechanisms and potential. J Immunol. 2010; 185 (10): 5677-82.

50. López P, Gueimonde M, Margolles A, Suárez A. Distinct Bifidobacterium strains drive different immune responses in vitro. Int J Food Microbiol. 2010; 138 (1-2): 157-65.

51. Caselli M, Vaira D, Cassol F, Calò G. Recombinant probiotics and their potential in human health. Int $\mathrm{J}$ Probiotics \& Prebiotics. 2012; 7 (2): 53-8.

52. Fedorova IA, Danilenko VN. Immunogenic properties of the probiotic component of the microbiota of the gastrointestinal tract. Biology Bulletin Reviews. 2014; 134 (2): 99-110.

53. Medina M, Izquierdo E, Ennahar S, Sanz Y. Differential immunomodulatory properties of Bifidobacterium logum strains: relevance to probiotic selection and clinical applications. Clin Exp Immunol. 2007 Dec; 150 (3): 531-8.

54. Khokhlova EV, Smeianov W, Efimov BA, Kafarskaia LI, Pavlova SI, Shkoporov AN. Anti-inflammatory properties of intestinal Bifidobacterium strains isolated from healthy infants. Microbiol Immunol. 2012 Jan; 56 (1): 27-39.

55. Averina OV, Ermolenko El, Ratushniy AYu, Tarasova EA, Borschev YuYu, Leontieva G F, i dr. Vlijanie probiotikov na produkciju citokinov $v$ sistemah in vitro $\mathrm{i}$ in vivo. Medicinskaja immunologija. 2015; 17 (5): 443-54.

56. Barbieri N, Villena J, Herrera M, Salva S, Alvarez S. Nasally administered Lactobacillus rhamnosus accelerate the recovery of humoral immunity in B lymphocyte-deficient malnourished mice. J Nutr. 2013 Feb; 143 (2): 227-35.

57. Tomosada Y, Chiba E, Zelaya H, Takahashi T, Tsukida K, Kitazawa H, et al. Nasally administered Lactobacillus rhamnosus strains

\section{Литература}

1. World Health Organization. Global tuberculosis report 2016. Доступно по ссылке: http://www.searo.who.int/tb/documents/ global-tuberculosis-report-2016/en/

2. Прозоров А. А., Зайчикова М. В., Даниленко В. Н. Мутанты Mycobacterium tuberculosis c множественной лекарственной устойчивостью: история появления, генетические и молекулярные механизмы устойчивости, возникающие проблемы. Генетика. 2012; 48 (1): 1-14.

3. Dean AS, Cox H, Zignol M. Epidemiology of Drug-Resistant Tuberculosis. Adv Exp Med Biol. 2017; 1019: 209-20.

4. Lange C, Chesov D, Heyckendorf J, Leung CC, Udwadia Z, Dheda K. Drug-resistant tuberculosis: An update on disease burden, diagnosis and treatment. Respirology. 2018. DOI: 10.1111/resp.13304. [Epub ahead of print].

5. D'Costa VM, McGrann KM, Hughes DW, Wright GD. Sampling the antibiotic resistome. Science. 2006; 311 (5759): 374-7.

6. Wright GD. The antibiotic resistome: the nexus of chemical and genetic diversity. Nat Rev Microbiol. 2007; 5 (3): 175-86.

7. Mikheecheva NE, Zaychikova MV, Melerzanov AV, Danilenko VN. A nonsynonymous SNP catalog of Mycobacterium tuberculosis virulence genes and its use for detecting new potentially virulent sublineages. Genome Biol Evol. 2017; 9 (4): 887-99.

8. Zaychikova MV, Zakharevich NV, Sagaidak MO, Bogolubova NA, Smirnova TG, Andreevskaya SN, et al. Mycobacterium tuberculosis Type II Toxin-Antitoxin Systems: Genetic Polymorphisms and Functional Properties and the Possibility of Their Use for Genotyping. PLoS One. 2015; 10: e0143682. differentially modulate respiratory antiviral immune responses and induce protection against respiratory syncytial virus infection. BMC Immunol. 2013 Aug; 15 (14): 40.

58. Leontieva GF, Kramskaya TA, Grabovskaya KB, Philimonova VY, Layno D, Villena D, i dr. Ispol'zovanie laktobacill $\vee$ kachestve ad"juvantov pri intranazal'noj immunizacii himernoj pnevmokokkovoj vakcinoj. Medicinskaja immunologija. 2016; 18 (6): 545-54.

59. Van Overtvelt L, Moussu H, Horiot S, Samson S, Lombardi V, Mascarell $\mathrm{L}$, et al. Lactic acid bacteria as adjuvants for sublingual allergy vaccines. Vaccine. 2010 Apr 9; 28 (17): 2986-92.

60. Harata G, He F, Hiruta N, Kawase M, Kubota A, Hiramatsu M, et al. Intranasally administered Lactobacillusgasseri TMC0356 protects mice from $\mathrm{H} 1 \mathrm{~N} 1$ influenza virus infection by stimulating respiratory immune responses. World J Microbiol Biotechnol. 2011; 27 (2): 411-16.

61. Gagneux S. Ecology and evolution of Mycobacterium tuberculosis. Nat Rev Microbiol. 2018 Apr; 16 (4): 202-13.

62. Merker M, Blin C, Mona S, Duforet-Frebourg N, Lecher S, Willery $\mathrm{E}$, et al. Evolutionary history and global spread of the Mycobacterium tuberculosis Beijing lineage. Nat Genet. 2015; 47 (3): 242-9.

63. Mokrousov I. Insights into the Origin, Emergence, and Current Spread of a Successful Russian Clone of Mycobacterium tuberculosis. Clin Microbiol Rev. 2013; 26 (2): 342-60.

64. Lyadova IV, Eruslanov EB, Khaidukov SV, Yeremeev W, Majorov KB, et al. Comparative analysis of $\mathrm{T}$ lymphocytes recovered from the lungs of mice genetically susceptible, resistant, and hyperresistant to Mycobacterium tuberculosis-triggered disease. J Immunol. 2000 Nov 15; 165 (10): 5921-31.

65. Zaychikova MV, Zakharevich NV, Chekalina MS, Danilenko VN CRISPR-Cas systems of Mycobacterium tuberculosis: the structure, evolutionary changes in different lineages, and a possible role in the promotion of virulence and resistance to drugs. Bulletin of Russian State Medical University. 2018; 2: 5-14. DOI: 10.24075/vrgmu.2018.015

66. Shitikov E, Bespyatykh J, Ischenko D, Alexeev D, Karpova I, Kostryukova E, et al. Unusual Large-Scale Chromosomal Rearrangements in Mycobacterium tuberculosis Beijing B0/W148 Cluster Isolates. PLoS One. 2014; 9 (1): e84971.
9. Reiling N, Homolka S, Kohl TA, Steinhäuser C, Kolbe K, Schütze S, et al. Shaping the niche in macrophages: Genetic diversity of the M. tuberculosis complex and its consequences for the infected host. Int J Med Microbiol. 2017; pii: S1438-4221 (17) 30294-1.

10. Reiling N, Homolka S, Walter K, Brandenburg J, Niwinski L, Ernst M, et al. Clade specific virulence patterns of Mycobacterium tuberculosis complex strains in human primarymacrophages and aerogenically infected mice. MBio. 2013; e00250-13.

11. Hanekom M, Gey van Pittius NC, McEvoy C, Victor TC, Van Helden PD, Warren RM. Mycobacterium tuberculosis Beijing genotype: a template for success. Tuberculosis (Edinb). 2011; 91 (6): 510-23.

12. Zaychikova MV, Mikheecheva NE, Belay YO, Alekseeva MG, Melerzanov AV, Danilenko VN. Single nucleotide polymorphisms of Beijing lineage Mycobacterium tuberculosis toxin-antitoxin system genes: their role in the changes of protein activity and evolution. Tuberculosis (Edinb). 2018; 112: 11-19.

13. Ebrahimi-Rad M, Bifani P, Martin C, Kremer K, Samper S, Rauzier J, et al. Mutations in putative mutator genes of Mycobacterium tuberculosis strains of the W-Beijing family. Emerg Infect Dis. 2003; 9 (7): 838-45.

14. Ribeiro SC, Gomes LL, Amaral EP, Andrade MR, Almeida FM, Rezende $\mathrm{AL}$, et al. Mycobacterium tuberculosis strains of the modern sublineage of the Beijing family are more likely to display increased virulence than strains of the ancient sublineage. J Clin Microbiol. 2014; 52 (7): 2615-24.

15. Kaufmann SH, Evans TG, Hanekom WA. Tuberculosis vaccines: 
time for a global strategy. Sci Transl Med. 2015; 7 (276): $276 f s 8$.

16. Chahine EB, Karaoui LR, Mansour H. Bedaquiline: a novel diarylquinoline for multidrug-resistant tuberculosis. Ann Pharmacother. 2014; 48 (1): 107-15.

17. Bekker OB, Sokolov DN, Luzina OA, Komarova NI, Gatilov YV, Andreevskaya SN, et al. Synthesis and activity of (+)-usnic acid and (-)-usnic acid derivatives containing 1,3-thiazole cycle against Mycobacterium tuberculosis. Med Chem Res. 2015; 24 (7): 2926-38.

18. Маслов Д. А., Беккер О. Б., Даниленко В. Н. Тест-система Mycobacterium smegmatis aphVIII+ для скрининга ингибиторов серин-треониновых протеинкиназ эукариотического типа. Патент РФ № 2566998, от 27.10.2015.

19. Маслов Д. А., Беккер О. Б., Алексеева М. Г., Князева Л. М., Мавлетова Д. А., Афанасьев И. И., и др. Ингибиторы серинтреониновых протеинкиназ классов аминопиридинов и аминопиримидинов - кандидаты в препараты для лечения лекарственноустойчивых форм туберкулеза. Вестник РГМУ 2017; 1: 42-7.

20. Krasnov VP, Vigorov AY, Musiyak W, Nizova IA, Gruzdev DA, Matveeva TV, et al. Synthesis and antimycobacterial activity of $\mathrm{N}$-(2-aminopurin-6-yl) and $\mathrm{N}$-(purin-6-yl) amino acids and dipeptides Bioorg Med Chem Lett. 2016; 26 (11): 2645-8.

21. Sala C, Hartkoorn RC. Tuberculosis drugs: new candidates and how to find more. Future Microbiol. 2011; 6 (6): 617-33.

22. Lechartier B, Rybniker J, Zumla A, Cole ST. Tuberculosis drug discovery in the post-post-genomic era. EMBO Mol Med. 2014; 6 (2): 158-68.

23. Danilenko VN, Osolodkin DI, Lakatosh SA, Preobrazhenskaya MN, Shtil AA. Bacterial eukaryotic type serine-threonine protein kinases: from structural biology to targeted anti-infective drug design. Curr Top Med Chem. 2011; 11 (11): 1352-69.

24. Cooper CB. Development of Mycobacterium tuberculosis whole cell screening hits as potential antituberculosis agents. J Med Chem. 2013; 56 (20): 7755-60.

25. Baulard AR, Betts JC, Engohang-Ndong J, Quan S, McAdam RA, Brennan PJ, et al. Activation of the pro-drug ethionamide is regulated in mycobacteria. J Biol Chem. 2000; 275 (36): $28326-$ 31.

26. Willand $N$, Dirié $B$, Carette $X$, Bifani $P$, Singhal $A$, Desroses $M$, et al. Synthetic EthR inhibitors boost antituberculous activity of ethionamide. Nat Med. 2009; 15 (5): 537-44.

27. Andries K, Verhasselt P, Guillemont J, Göhlmann HW, Neefs JM, Winkler $\mathrm{H}$, et al. A diarylquinoline drug active on the ATP synthase of Mycobacterium tuberculosis. Science. 2005; 307 (5707): 223-7.

28. Ananthan S, Faaleolea ER, Goldman RC, Hobrath JV, Kwong CD, Laughon BE, et al. High-throughput screening for inhibitors of Mycobacterium tuberculosis H37Rv. Tuberculosis (Edinb). 2009; 89 (5): 334-53

29. Ballell L, Bates RH, Young RJ, Alvarez-Gomez D, Alvarez-Ruiz E, Barroso V, et al. Fueling open-source drug discovery: 177 smallmolecule leads against tuberculosis. Chem Med Chem. 2013; 8 (2): 313-21.

30. Zhang Y, Mitchison D. The curious characteristics of pyrazinamide: a review. Int J Tuberc Lung Dis. 2003; 7 (1): 6-21.

31. Zhang Y, Chiu Chang K, Leung C-C, Wai Yew W, Gicquel B, Fallows D, et al. 'ZS-MDR-TB' versus 'ZR-MDR-TB': improving treatment of MDR-TB by identifying pyrazinamide susceptibility. Emerg Microbes Infect. 2012; 1 (7): e5.

32. Maslov DA, Zaĭchikova MV, Chernousova LN, Shur KV, Bekker OB, Smirnova TG, et al. Resistance to pyrazinamide in Russian Mycobacterium tuberculosis isolates: pncA sequencing versus Bactec MGIT 960. Tuberculosis (Edinb). 2015; 95 (5): 608-12.

33. Mangtani $\mathrm{P}$, Abubakar I, Ariti $\mathrm{C}$, Beynon R, Pimpin L, Fine PE, et al. Protection by BCG vaccine against tuberculosis: a systematic review of randomized controlled trials. Clin Infect Dis. 2014; 58 (4): 470-80.

34. Kaufmann SH, Weiner J, von Reyn CF. Novel approaches to tuberculosis vaccine development. Int J Infect Dis. 2017; 56: 263-7.

35. Méndez-Samperio P. Global Efforts in the Development of Vaccines for Tuberculosis: Requirements for Improved Vaccines
Against Mycobacterium tuberculosis. Scand J Immunol. 2016; 84 (4): 204-10.

36. Andersen $\mathrm{P}$, Kaufmann $\mathrm{SH}$. Novel vaccination strategies against tuberculosis. Cold Spring Harb Perspect Med. 2014; 4 (6). pii: a018523.

37. Forrellad MA, Klepp L, Gioffré A, Sabioy García J, Morbidoni HR, de la Paz Santangelo $M$, et al. Virulence factors of the Mycobacterium tuberculosis complex. Virulence. 2013; 4 (1): 3-66.

38. Brosch R, Gordon SV, Garnier T, Eiglmeier K, Frigui W, Valenti P, et al. Genome plasticity of BCG and impact on vaccine efficacy. Proc Natl Acad Sci USA. 2007; 104 (13): 5596-601.

39. Uranga S, Marinova D, Martin C, Aguilo N. Protective Efficacy and Pulmonary Immune Response Following Subcutaneous and Intranasal BCG Administration in Mice. J Vis Exp. 2016; 115. DOl: $10.3791 / 54440$.

40. Zimmermann N, Thormann V, Hu B, Köhler AB, Imai-Matsushima A, Locht $C$, et al. Human isotype-dependent inhibitory antibody responses against Mycobacterium tuberculosis. EMBO Mol Med. 2016; 8 (11): 1325-39.

41. Alvarez N, Infante JF, Borrero R, Mata D, Payan JB, Hossain MM et al. Histopathological Study of the Lungs of Mice Receiving Human Secretory IgA and Challenged with Mycobacterium tuberculosis. Malays J Med Sci. 2014; 21 (3): 31-7.

42. Alvarez N, Otero O, Camacho F, Borrero R, Tirado Y, Puig A, et al. Passive administration of purified secretory IgA from human colostrum induces protection against Mycobacterium tuberculosis in a murine model of progressive pulmonary infection. BMC Immunol. 2013; 14 (Suppl 1): S3.

43. Savelkoul HFJ, Ferro VA, Strioga MM, Schijns VEJ.C. Choice and Design of Adjuvants for Parenteral and Mucosal Vaccines. Vaccines (Basel). 2015; 3 (1): 148-71.

44. Edelman R. Vaccine adjuvants. Rev Infect Dis. 1980; 2 (3): 370-83.

45. Pouwels PH, Leer RJ, Shaw M, Heijne den Bak-Glashouwer MJ, Tielen FD, Smit E, et al. Lactic acid bacteria as antigen delivery vehicles for oral immunization purposes. Int J Food Microbiol. 1998; 41 (2): 155-67.

46. Bessler WG, Huber M, Baier W. Bacterial cell wall components as immunomodulators-II. The bacterial cell wall extract OM-85 BV as unspecific activator, immunogen and adjuvant in mice Int $J$ Immunopharmacol. 1997; 19 (9-10): 551-8.

47. López P, González-Rodríguez I, Sánchez B, Gueimonde M, Margolles A, Suárez A. Treg-inducing membrane vesicles from Bifidobacterium bifidum LMG13195 as potential adjuvants in immunotherapy. Vaccine. 2012; 30 (5): 825-9.

48. Medina E, Talay SR, Chhatwal GS, Guzmán CA. Fibronectinbinding protein I of Streptococcus pyogenes is a promising adjuvant for antigens delivered by mucosal route. Eur $\mathrm{J}$ Immunol. 1998; 28 (3): 1069-77.

49. Mizel SB, Bates JT. Flagellin as an adjuvant: cellular mechanisms and potential. J Immunol. 2010; 185 (10): 5677-82.

50. López P, Gueimonde M, Margolles A, Suárez A. Distinct Bifidobacterium strains drive different immune responses in vitro. Int J Food Microbiol. 2010; 138 (1-2): 157-65.

51. Caselli M, Vaira D, Cassol F, Calò G. Recombinant probiotics and their potential in human health. Int J Probiotics \& Prebiotics. 2012; 7 (2): 53-8

52. Федорова И. А., Даниленко В. Н. Иммуногенные свойства пробиотического компонента микробиоты желудочнокишечного тракта. Успехи современной биологии. 2014; 134 (2): 99-110.

53. Medina M, Izquierdo E, Ennahar S, Sanz Y. Differential immunomodulatory properties of Bifidobacterium logum strains: relevance to probiotic selection and clinical applications. Clin Exp Immunol. 2007 Dec; 150 (3): 531-8.

54. Khokhlova EV, Smeianov W, Efimov BA, Kafarskaia LI, Pavlova SI, Shkoporov AN. Anti-inflammatory properties of intestinal Bifidobacterium strains isolated from healthy infants. Microbiol Immunol. 2012 Jan; 56 (1): 27-39.

55. Аверина О. В., Ермоленко Е. И., Ратушный А. Ю., Тарасова Е. А., Борщев Ю. Ю., Леонтьева Г. Ф., и др. Влияние пробиотиков на продукцию цитокинов в системах in vitro $n$ in vivo. Медицинская иммунология. 2015; 17 (5): 443-54 
56. Barbieri N, Villena J, Herrera M, Salva S, Alvarez S. Nasally administered Lactobacillus rhamnosus accelerate the recovery of humoral immunity in B lymphocyte-deficient malnourished mice. J Nutr. 2013; Feb; 143 (2): 227-35.

57. Tomosada Y, Chiba E, Zelaya H, Takahashi T, Tsukida K, Kitazawa H, et al. Nasally administered Lactobacillus rhamnosus strains differentially modulate respiratory antiviral immune responses and induce protection against respiratory syncytial virus infection. BMC Immunol. 2013 Aug; 15 (14): 40.

58. Леонтьева Г. Ф., Крамская Т. А., Грабовская К. Б., Филимонова В. Ю., Лайно Д., Виллена Д., и др. Использование лактобацилл в качестве адъювантов при интраназальной иммунизации химерной пневмококковой вакциной. Медицинская иммунология. 2016; 18 (6): 545-54.

59. Van Overtvelt L, Moussu H, Horiot S, Samson S, Lombardi V, Mascarell $L$, et al. Lactic acid bacteria as adjuvants for sublingual allergy vaccines. Vaccine. 2010 Apr 9; 28 (17): 2986-92.

60. Harata G, He F, Hiruta N, Kawase M, Kubota A, Hiramatsu M, et al. Intranasally administered Lactobacillusgasseri TMC0356 protects mice from $\mathrm{H} 1 \mathrm{~N} 1$ influenza virus infection by stimulating respiratory immune responses. World J Microbiol Biotechnol. 2011; 27 (2): 411-16.

61. Gagneux S. Ecology and evolution of Mycobacterium tuberculosis. Nat Rev Microbiol. 2018 Apr; 16 (4): 202-13.
62. Merker M, Blin C, Mona S, Duforet-Frebourg N, Lecher S, Willery $\mathrm{E}$, et al. Evolutionary history and global spread of the Mycobacterium tuberculosis Beijing lineage. Nat Genet. 2015; 47 (3): 242-9.

63. Mokrousov I. Insights into the Origin, Emergence, and Current Spread of a Successful Russian Clone of Mycobacterium tuberculosis. Clin Microbiol Rev. 2013; 26 (2): 342-60.

64. Lyadova IV, Eruslanov EB, Khaidukov SV, Yeremeev W, Majorov KB, et al. Comparative analysis of $\mathrm{T}$ lymphocytes recovered from the lungs of mice genetically susceptible, resistant, and hyperresistant to Mycobacterium tuberculosis-triggered disease. J Immunol. 2000 Nov 15; 165 (10): 5921-31.

65. Зайчикова М. В., Захаревич Н. В., Чекалина М. С., Даниленко В. Н. CRISPR-Cas системы Mycobacterium tuberculosis: структура модуля, изменение в процессе эволюции у различных линий, возможная роль в формировании вирулентности и лекарственной устойчивости. Вестник РГМУ. 2018; 2: 5-14. DOI: 10.24075/ vrgmu.2018.015

66. Shitikov E, Bespyatykh J, Ischenko D, Alexeev D, Karpova I, Kostryukova E, et al. Unusual Large-Scale Chromosomal Rearrangements in Mycobacterium tuberculosis Beijing B0/N148 Cluster Isolates. PLoS One. 2014; 9 (1): e84971. 